\title{
DRAIN AMYLASE ON THE FIRST POSTOPERATIVE DAY OF WHIPPLE SURGERY: WHAT VALUE IS THE BEST PREDICTOR FOR EARLY DRAIN REMOVAL?
}

Amilase do dreno no primeiro dia de pós-operatório de operaçao de Whipple: qual valor é melhor preditor para a retirada precoce do dreno?

Enio Campos AMICO', Ítalo Medeiros de AZEVEDO', Marcos Vinicius de Lira FERNANDES',

Mariane Albuquerque REIS', Samir Assi JOÃO

How to cite this article: Amico EC, Azevedo IM , Fernandes MML, Reis MA, João SA. Drain amylase on the first postoperative day of Whipple surgery: What value is the best predictor for early drain removal? ABCD Arq Bras Cir Dig. 2018;31(1):e1345. DOI: /10.1590/0102-672020180001e1345

From the ${ }^{1}$ Departamento de Medicina Integrada, Universidade Federal do Rio Grande do Norte, Hospital Universitário Onofre Lopes ('Department of Integrated Medicine, Federal University of Rio Grande do Norte, University Hospital Onofre Lopes), Natal, RN, Brazil

HEADINGS - Amylase. Postoperative complications. Pancreatic fistula. Pancreatoduodenectomy
ABSTRACT - Background: The value of drain amylase on the first postoperative day after pancreatic resections has been described as an efficient predictor of pancreatic fistula. In spite of this, the cut-off point below which the drains can be removed early remains controversial. Aim: Validate the use of the amylase on the $1^{\text {st }}$ postoperative day in the correlation with pancreatic fistula and define the value at which early drain removal is safe. Method: Were included patients undergoing Whipple surgery in the period of 2007 to 2016. Group 1 enrolled the ones who did not develop fistula and those who developed biochemical fistula for less than seven days postoperatively and group 2 included patients who developed persistent biochemical fistula between seven and 21 days and those with grade $B$ and $C$ fistula. Results: Sixty-one patients were included, 41 comprised group 1 and 20 group 2. The incidence of abdominal collections, need for reoperation and time of hospitalization were for group 1 and 2, respectively: $17.1 \%, 17.1 \%$ and 9.5 days, and $65 \%, 40 \%$ and 21.1 days. The median of the amylase from the drain at $1^{\text {st }}$ postoperative day was in group 1 and 2, respectively: $175 \mathrm{U} / \mathrm{l}$ and $3172.5 \mathrm{U} / \mathrm{I}(\mathrm{p}=0.001)$. Using a cut-off of 180 to predict the group to which the patient would belong there was obtained sensitivity, specificity, positive predictive value and negative predictive value of $100 \%, 48.8 \%, 50 \%$ and $100 \%$ respectively. Conclusion: It was validated the cut-off value of $180 \mathrm{U} / \mathrm{l}$ as appropriate to early drain removal.

\section{Correspondence: \\ Enio Campos Amico \\ E-mail: ecamic@uol.com.br;}

Financial source: none

Conflict of interest none

Received for publication: 21/11/2017 Accepted for publication: 30/01/2018

DESCRITORES - Amilase. Complicações pós-operatórias. Fístula pancreática. Pancreatoduodenectomia.
RESUMO - Racional: O valor da amilase do dreno no primeiro dia pós-operatório após ressecções pancreáticas é descrito como eficiente preditor de fístula pancreática. Entretanto, o valor abaixo do qual os drenos podem ser removidos precocemente permanece controverso. Objetivo: Validar o uso da amilase do primeiro dia pós-operatório na correlação com a fístula pancreática e definir o valor em que seja segura a retirada precoce do dreno. Método: Foram incluídos pacientes submetidos à operação de Whipple no período de 2007 a 2016. No grupo 1 entraram os que não desenvolveram fístula e os que desenvolveram fístula bioquímica por menos de sete dias de pós-operatório e no grupo 2 os que desenvolveram fístula bioquímica persistente entre 7 e 21 dias e aqueles com fístula grau B e C. Resultados: Sessenta e um pacientes foram incluídos, sendo 41 do grupo 1 e 20 do grupo 2 . A incidência de coleções abdominais, necessidade de reoperação e tempo de internação foram para o grupo 1 e 2, respectivamente $17,1 \%, 17,1 \%$ e 9,5 dias, e $65 \%, 40 \%$ e 21,1 dias. A mediana da amilase no grupo 1 e 2, respectivamente foi de $175 \mathrm{U} / \mathrm{l}$ e $3172,5 \mathrm{U} / \mathrm{I}(\mathrm{p}=0,001)$. Utilizando o ponto de corte de 180 para predizer o grupo a que o paciente pertenceria, obteve-se sensibilidade, especificidade, valor preditivo positivo e valor preditivo negativo de: $100 \%, 48,8 \%, 50 \%$ e $100 \%$ respectivamente. Conclusão: Esta amostra pôde validar o ponto de corte de $180 \mathrm{U} / \mathrm{l}$ como adequado para a retirada precoce do dreno.
$\mathrm{H}$ istorically, abdominal drains have been utilized at the end of gastrointestinal surgeries with the objective of removing blood, pancreatic juices, lymph, and other secretions that could be present. Besides, it is an efficient manner to identify pancreatic fistulas (PF) and even treat them ${ }^{16}$. In the last 25 years, some studies have suggested that abdominal drains placed after duodenopancreatectomy can cause negative effects due to the risk of contamination of the abdominal cavity or even due to direct lesions of the intestinal loops or anastomosis ${ }^{13,11}$. There are few studies that have randomized the use (or not) of systematic prophylactic drains in pancreatic resections, with conflicting results $8,18,19$, which has been a limiting factor in the practice of not using drains in this type of procedure.

Description of correlation between drain amylase in the $1^{\text {st }}$ postoperative day (AD1PO) after pancreatic resections and development of PF has stimulated a new approach to manage these patients. The idea is to substitute the non-utilization 
of drains in a systematic manner for early removal in those cases where AD1PO dosage is considered low. Several studies have attempted to define an ideal cut-off point for this scenario and variations are as wide as $5.000 \mathrm{U} / \mathrm{L}^{6}$ and $90 \mathrm{U} / \mathrm{I}^{14}$ have been suggested.

The objective of the study presented herein is, from a cohort of patients submitted prospectively to duodenopancreatectomy, validate the use of AD1PO in the correlation with PF and define the most adequate cut-off point for early removal of drains in a group of patients.

\section{METHOD}

The project was submitted and approved by the Human Research Ethics Committee, under n 59716616.9.0000.5292 in the Plataforma Brasil.

Sixty-three patients were analyzed from a prospective database, who had undergone Kausch-Whipple surgery performed by the $1^{\text {st }}$ author of this study (ECA), for the treatment of pancreatic or peripancreatic diseases. The time period was between June 2007 and September 2016, in the following hospitals located in the city of Natal: Hospital Universitário Onofre Lopes, Liga Norte Riograndense Contra o Câncer, Casa de Saúde São Lucas and Natal Hospital Center.

The technical steps for the Whipple technique as performed by the author are detailed in previous studies ${ }^{1,2}$. Three techniques for pancreatojejunal anastomosis were utilized. For pancreas with main pancreatic duct $\geq 5 \mathrm{~mm}$, two-layer pancreatojejunal terminolateral duct to mucosa anastomosis was performed. For pancreas with normal or slightly dilated (diameter $<5 \mathrm{~mm}$ ) main pancreatic duct, terminoterminal pancreatojejunal anastomosis ("telescopic") or terminolateral pancreatojejunal anastomosis ("invagination") were carried out, the latter performed systematically after the $33^{\text {rd }}$ patient from the casebook. At the end of the surgery, two drains, preferably laminar silicone drains, were placed in the cavity and exteriorized at each flank.

In the majority of patients, subcutaneous octreotide was utilized as prophylaxis for the prevention of PF, at 0.3 $\mathrm{mg} /$ day, fractioned in $8 \mathrm{~h}$ intervals, during seven days. Debits were recorded along with amylase dosage of the drained liquid on the $1^{\text {st }}, 3^{\text {rd }}, 5^{\text {th }}, 7^{\text {th }}$ and sometimes, on the $9^{\text {th }}$ postoperative day. The value of AD1PO vas defined from the highest amylase value of both drains, measured from a sample of liquid obtained on the first day after surgery.

PF diagnosis utilized the 2016 revised criterion of GIEDFP ${ }^{3}$. PF was defined when on the $3^{\text {rd }}$ postoperative (PO) day the value of amylase in the drained liquid was three times higher than the normal upper limit for serum amylase. Patients that did not develop fistula or those with transient biochemical fistula ( $<7$ days $\mathrm{PO}$ ) were characterized as group 1, and patients with persistent biochemical fistula (between 7 and 21 days PO) and fistula grade B and C were characterized as group 2 . In most cases, on the $9^{\text {th }}$ day after surgery, control ultrasound or tomography tests were carried out. Removal of drains occurred in those cases with low amylase values for the drained liquid (under three times the upper limit for normal serum amylase) and when image tests did not show abdominal collections. Intrahospital mortality was defined as death occurring within 90 days of surgery.

The Receiver Operating Characteristic (ROC) curve was utilized to identify an adequate cut-off point for AD1PO and verify its predictive characteristic in patients of both groups. The ROC value was generated after sensitivity, specificity and accuracy calculations. Additionally, the cut-off point $578 \mathrm{U} / \mathrm{I}$ was also selected because of its closeness to the value utilized by Fong e cols ${ }^{9}$, for comparison purposes.

\section{Statistical analysis}

After determination of the cut-off point, the association was verified by Fisher's Exact test. The odds ratio (OR) was also calculated. The hypothesis tested was that AD1PO levels were different in groups 1 and 2, utilizing Mann-Whitney's test. Chi-squared and Fisher's tests were applied to verify the association between demographic and clinical variables with different groups. Statistical package SPSS ${ }^{\circledR} 21$ was utilized. A $5 \%$ significance level was applied to all tests.

\section{RESULTS}

From the initial sample of 63 patients, two were excluded. One had AD1PO collected incorrectly on the $2^{\text {nd }}$ day after surgery, and the other passed within the $1^{\text {st }}$ week PO. Therefore analysis covered 61 patients. Group 1 was constituted of 41 patients, of which 36 did not develop fistula and five transient biochemical fistula (grade A). Group 2 was constituted of 20 patients, of which six presented persistent biochemical fistula (grade A), eight degree B fistula, and six grade $C$ fistula. The index of clinical fistula (grades $B+C$ ) in the overall sample was $22.9 \%$.

The demographic and clinical characteristics of the patients, as well as respective tests, are shown in Table 1. There was no statistical difference between groups regarding age, gender and type of illness. However, regarding the size of main pancreatic duct and type of anastomosis, a statistically significant difference was detected. All patients with dilated main pancreatic ducts as well as those submitted to duct to mucosa anastomosis belonged to group 1 .

TABLE 1 - Associations between demographic and clinical characteristics and patient groups

\begin{tabular}{|c|c|c|c|c|c|}
\hline \multirow[t]{3}{*}{ Variables } & \multicolumn{2}{|c|}{ Group 1} & \multicolumn{2}{|c|}{ Group 2} & \multirow{3}{*}{$\begin{array}{c}p \\
0.706 "\end{array}$} \\
\hline & \multicolumn{2}{|c|}{$58.0 \pm 13.06$} & \multicolumn{2}{|c|}{$57.1 \pm 12.1^{\prime}$} & \\
\hline & $\mathrm{n}$ & $\%$ & $\mathrm{n}$ & $\%$ & \\
\hline \multicolumn{6}{|l|}{ Gender } \\
\hline Male & 19 & 63.3 & 11 & 36.7 & \multirow{2}{*}{$0.525 "$} \\
\hline Female & 22 & 71.0 & 9 & 29.0 & \\
\hline \multicolumn{6}{|l|}{ Disease } \\
\hline Pancreatic adenocarcinoma & 17 & 65.4 & 9 & 34.6 & \multirow{6}{*}{$0.264^{\prime \prime}$} \\
\hline Papillary adenocarcinoma & 12 & 60.0 & 8 & 40.0 & \\
\hline Duodenal adenocarcinoma & 1 & 33.3 & 2 & 66.7 & \\
\hline Colangiocarcinoma & 4 & 100.0 & 0 & 0.0 & \\
\hline Frantz & 5 & 100.0 & 0 & 0.0 & \\
\hline Others & 2 & 66.7 & 1 & 33.3 & \\
\hline \multicolumn{6}{|l|}{ Size of duct } \\
\hline$<5$ & 31 & 60.8 & 20 & 39.2 & \multirow{2}{*}{$0.023^{1 \mathrm{~V}}$} \\
\hline$>5$ & 10 & 100.0 & 0 & 0.0 & \\
\hline \multicolumn{6}{|l|}{ Anastomosis* } \\
\hline T-L (Invagination) & 14 & 50.0 & 14 & 50.0 & \multirow{3}{*}{$0.011^{\prime \prime}$} \\
\hline $\mathrm{T}-\mathrm{T}$ & 17 & 73.9 & 6 & 26.1 & \\
\hline $\mathrm{T}-\mathrm{L}(\mathrm{DM})$ & 10 & 100.0 & 0 & 0.0 & \\
\hline
\end{tabular}

I=mean \pm standard deviation; II=Mann-Whitney's test; III= Chi-squared test; IV= Fisher's exact test; ${ }^{*} \mathrm{~T}-\mathrm{L}=$ terminolateral; $\mathrm{T}-\mathrm{T}=$ terminoterminal; $\mathrm{T}-\mathrm{L}(\mathrm{DM})=$ terminolateral (duct to mucosa)

Regarding postoperative evolution, group 2 was associated with a higher level of general complications, postoperative collections, longer permanence of abdominal drain and hospitalization time. There was also an association between high resurgery index and patients of group 2. Nevertheless, despite all these worse result factors related to group 2, there was no statistically significant difference when comparing mortality across groups (Table 2). 
TABLE 2 - Associations between postoperative clinical findings and patient groups, along with results for drain and hospitalization times, per group

\begin{tabular}{|c|c|c|c|c|c|}
\hline \multirow{2}{*}{ Variable } & \multicolumn{2}{|c|}{ Group 1} & \multicolumn{2}{|c|}{ Group 2} & \multirow[b]{2}{*}{$\mathrm{p}$} \\
\hline & $\mathrm{n}$ & $\%$ & $\mathrm{n}$ & $\%$ & \\
\hline \multicolumn{6}{|l|}{ Collection } \\
\hline Yes & 7 & 33.3 & 14 & 66.7 & \multirow{2}{*}{$<0.001^{1}$} \\
\hline No & 34 & 85.0 & 6 & 15.0 & \\
\hline \multicolumn{6}{|c|}{ Postoperative complications } \\
\hline Yes & 20 & 50.0 & 20.0 & 50.0 & \multirow{2}{*}{$<0.001^{\prime \prime}$} \\
\hline No & 21 & 100.0 & 0 & 0.0 & \\
\hline \multicolumn{6}{|l|}{ Resurgery } \\
\hline Yes & 7 & 46.7 & 8 & 53.3 & \multirow{2}{*}{$0.051^{\prime}$} \\
\hline No & 34 & 73.9 & 12 & 26.1 & \\
\hline \multicolumn{6}{|c|}{ 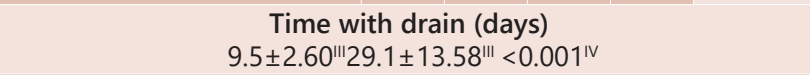 } \\
\hline \multicolumn{6}{|c|}{ 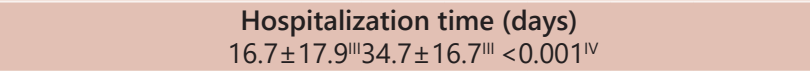 } \\
\hline Mortality & 4 & 9.8 & 1 & 5.0 & $1.000^{\prime \prime}$ \\
\hline
\end{tabular}

Mortality of the series was $8.19 \%$ : four patients belonged to group 1 and one patient to group 2 . The mortality causes in group 1 were:kidney insufficiency due to coagulopathy; dehiscence of gastrojejunal anastomosis and sepsis, pneumonia due to broncoaspiration and necrosis of the pancreaticojejunostomy loop associated with sepsis. The only patient of group 2 passed due to necrotic pancreatitis associated with pancreatic fistula and sepsis.

Regarding the AD1PO value, the median was $175 \mathrm{U} / \mathrm{I}$ (48.5-954) in group 1 and $2172.5 \mathrm{U} / \mathrm{I}$ (833.5-6421.0) in group 2. This difference was statistically significant $(p=0.001)$.

The area under the ROC curve presented an exactness index of $83.0 \%(p=0.001)$. When considering a $180 \mathrm{U} / \mathrm{l}$ cut-off point for AD1PO, the following results were obtained: sensitivity $100 \%$, specificity $48.8 \%$, positive predictor value $50 \%$, and negative predictor value $100 \%$. There was an association between the arbitrated AD1PO value from the ROC curve $(>180 \mathrm{U} / \mathrm{l})$ with groups 1 and 2 ( $p<0.001)$. With a cut-off point of $578 \mathrm{U} / \mathrm{l}$, the results were: sensitivity $80 \%$, specificity $39 \%$, positive predictor value $50 \%$ and negative predictor value $86.2 \%$. There was also an association between the arbitrated AD1PO value from the ROC curve $(>578 \mathrm{U} / \mathrm{l})$ with groups 1 and $2(\mathrm{p}<0.003)$. Patients presenting AD1PO values higher than $180 \mathrm{U} / \mathrm{I}$ and $578 \mathrm{U} / \mathrm{I}$ were 2.0 and 6.25 times more likely to belong to group 2, and therefore require postoperative drainage. Table 3 shows the comparison between the two AD1PO values.

TABLE 3 - Precision and exactness measurements, per AD1PO cut-off point

\begin{tabular}{|c|c|c|}
\hline \multirow{2}{*}{ Parameters } & \multicolumn{2}{|c|}{ Cut-off point (U/I) } \\
\hline & 180 & 578 \\
\hline Sensitivity & $100 \%$ & $80 \%$ \\
\hline Specificity & $48.8 \%$ & $39 \%$ \\
\hline VPP & $50 \%$ & $50 \%$ \\
\hline VPN & $100 \%$ & $86.2 \%$ \\
\hline
\end{tabular}

\section{DISCUSSION}

AD1PO as a predictor of post-pancreatectomy PF was described by Yamaguchi e cols in $2003^{20}$. The authors analyzed the amylase values measured in abdominal drains of 26 patients submitted to pancreatectomy, and observed that values were already high on the first day PO in those who developed clinical PF after. At least three meta-analysis ${ }^{10,15,21}$ have validated the correlation between high AD1PO values and the development of PF. However, there is still controversy on the adequate cut-off point for AD1PO to predict PF, and on its applicability to the removal of prophylactic drains inserted after pancreatic resections. Verona's group was the first to establish a strategy for the early removal of abdominal drains based on AD1PO values ${ }^{6}$. The authors carried out a prospective study on 114 patients submitted to pancreatic resection and randomized those with AD1PO $<5000 \mathrm{U} / \mathrm{I}$ to remove the drain on the $3^{\text {rd }}$ or $5^{\text {th }}$ day PO. Early removal of drains was associated with a lower rate of pancreatic fistula ( $1.8 \%$ vs. $26 \%)$, lower rate of abdominal complications ( $12.2 \%$ vs. $52.6 \%)$, lower rate of pulmonary complications $(26.3 \%$ vs. $52.6 \%)$, shorter hospitalization times $(8.7( \pm 4)$ vs. $10.8( \pm 6.9)$ and lower hospital readmission rates ( $0 \%$ vs. $8.8 \%$ ). Although the study suggested that early removal of abdominal drains was safe with AD1PO under $5000 \mathrm{U} / \mathrm{l}$, other authors reported hypothetical PF indexes between $25-48 \%$ if drains were removed according to this suggestion ${ }^{7,12}$.

For those patients submitted to duodenopancreatectomy and that received prophylactic drains, the most important question is to know which patients will not develop PF - and not the other way around. On one hand, knowing which patients will not develop PF is useful because it allows for early drain removal, which leads to shorter hospitalization times. On the other hand, predicting which patients will develop PF after surgery, when the abdominal cavity is being drained, is not as relevant because PF can be easily diagnosed by measuring amylase in the drained liquid. In most cases, treatment is simple maintenance of drains, associated with fasting and nutritional support. For this reason the study herein presented analyzed two low AD1PO cut-off points ( 180 and 578 ) that were associated with higher specificity and consequently, with a high negative predictive factor, in detriment to a high cut-off point associated with higher sensitivity to PF diagnosis. Another reason for the selection is related to the impossibility of obtaining daily interventionist radiology services in the public hospital where the majority of the patients studied underwent surgery. These services include percutaneous drainage of abdominal collections/abscesses, which is indicated in urgent cases where there are abdominal complications as a consequence of undrained anastomotic leaks.

The methodology of this study utilized the PF definition based on the revised classification by ISGPS 5 , which no longer considers grade $A$ of the previous classification to be a true $\mathrm{PF}^{4}$. However, as this study aimed at identifying a group of patients in which early removal of drains could be beneficial, it was important to include not only the concept of PF, but also grades $B$ and $C$ and those patients with biochemical fistula that persisted with amylase-rich debit between 7-21 days PO. In these patients, early removal of drains would increase susceptibility to abdominal collections or abscesses. With the $180 \mathrm{U} / \mathrm{l}$ cut-off point, an excellent correlation was obtained between AD1PO and absence of fistula. Therefore it was possible to identify $1 / 3$ of patients that would have been benefitted by early drain removal. Besides, with the same cut-off, none of the patients that developed clinically relevant fistula or even persistent biochemical fistula would have had their drains removed early.

Data obtained herein were capable of validating previous publications that utilized low cut-off points $7,12,14,17$. Differently from these studies, however, the first series was entirely prospective herein, including only patients submitted consecutively to duodenopancreatectomy by a single team of surgeons, where PF definition followed ISGPS criteria. The cut-off point $180 \mathrm{U} / \mathrm{l}$ obtained herein was lower than the one found by Fong et $\mathrm{al}^{9}$ at the Massachusetts General Hospital. They divided the study in two cohorts: the first involved 126 patients, and the $612 \mathrm{U} / \mathrm{l}$ cut-off 
point was defined as the one presenting best accuracy, sensitivity and specificity; the second had the objective of validating a $600 \mathrm{U} / \mathrm{l}$ cut-off point, involving 369 patients submitted to duodenopancreatectomy within January 2009 and December 2012. Almost two-thirds of patients (62.1\%) presented AD1PO lower than $600 \mathrm{U} / \mathrm{l}$ and only two PF cases $(0.9 \%)$ were diagnosed. This was different than the other patients with AD1PO of at least $600 \mathrm{U} / \mathrm{l}$, with PF incidence of $31.4 \%$. When considering herein a cut-off point close to Fong et al., $578 \mathrm{U} / \mathrm{I}, 13.8 \%$ of patients with PF diagnosis would have been affected by early removal of drains (negative predictor value: $86.2 \%$ ). In the reality considered herein, there is no non-invasive treatment for intracavitary collections/abscesses available all the time at the public hospital, and therefore increasing the cut-off point would be a high price to pay.

This study presents some limitations. The first concerns the low number of included patients, which did not hinder statistical analysis. The second is related to the nonverification of the real benefits of drains in patients who developed PF, as all patients received drains. The high index of abdominal collections (65\%) and necessity of re-surgery (40\%) in group 2 suggested that, for some patients, drains were not totally efficient; nevertheless, the objective of the study was to find a group of patients in which drains could be removed early and not confirm the non-efficiency of drains in the group that developed PF.

\section{CONCLUSION}

Was validated the $180 \mathrm{U} / \mathrm{l}$ cut-off point as adequate to define those patients in which abdominal drains can be removed early after duodenopancreatectomy. At the same time it is recognized that there is no ideal cut-off point to be utilized uniformly in all services. The ideal cut-off point must vary in accordance with the specifications of the service and compensate for the risk of undrained PF with the benefits of a faster recovery in a higher number of patients.

\section{REFERENCES}

1. Amico Enio Campos, Alves José Roberto, João Samir Assi, Guimarães Priscila Luana Franco Costa, Barreto Élio José Silveira da Silva, Barreto Leonardo Silveira da Silva et al . Complications after pancreatectomies: prospective study after ISGFP and ISGPS new classifications. ABCD, arq. bras. cir. dig. [Internet]. 2013 Sep [cited 2016 Sep 17] ; 26( 3 ): 213-218.

2. Amico EC, José \&, Barreto SS, José, Alves R, João SA, et al. Cinquenta pancreatectomias consecutivas sem mortalidade. Rev. Col. Bras. Cir.2016;43(1):6-11.
3. Bassi, Claudio et al. The 2016 update of the International Study Group (ISGPS) definition and grading of postoperative pancreatic fistula: 11 Years After. Surgery, 2017 Mar;161(3):584-591.

4. Bassi C, Dervenis C, Butturini G, et al. Postoperative pancre- atic fistula: an international study group (ISGPF) definition. Surgery 2005;138:8-13.

5. Bassi C, Marchegiani G, Dervenis C, Sarr M, Hilal MA, Adam M et all. The 2016 update of the International Study Group (ISGPS) definition and grading of postoperative pancreatic fistula: 11 Years After. Surgery 2016

6. Bassi C, Molinari E, Malleo G, Crippa S, Butturini G, Salvia R, Talamini G, Pederzoli P. Early Versus Late Drain Removal After Standard Pancreatic Resections. Results of a Prospective Randomized Trial. Ann Surg. 2010 Aug;252(2):207-14.

7. Bertens KA, Crown A, Clanton J, Alemi F, Alseidi AA, Biehl T, Helton WS Rocha FG. What is a better predictor of clinically relevant postoperative pancreatic fistula (CR-POPF) following pancreaticoduodenectomy (PD): postoperative day one drain amylase (POD1DA) or the fistula risk score (FRS)? HPB 2016, 1-7

8. Conlon KC, Labow D, Leung D, et al. Prospective randomized clinical trial of the value of intraperitoneal drainage after pancreatic resection. Ann Surg. 2001;234:487-493.

9. FongZV,Correa-GallegoC, FerroneCR, VeilletteGR, WarshawAL, Lillemoe KDetal. Earlydrain removal - the middleground between thedrainversus no drain debate in patients undergoing pancreaticoduodenectomy. A prospective validation study. Ann Surg 262:378 - 383. 2015.

10. Giglio MC. Meta-analysis of drain amylase content on postoperative day 1 as a predictor of pancreatic fistula following pancreatic resection.

11. HeslinMJ,HarrisonLE, BrooksAD, etal.Isintra-abdominaldrainagenecessary after pancreaticoduodenectomy? J Gastrointest Surg. 1998;2:373-378.

12. Israel JS, Rettammel RJ, Leverson GE, Hanks LR, Cho CS, Winslow ER. Does postoperative drain amylase predict pancreatic fistula after pancreatectomy? J Am Coll Surg. Vol. 218, No. 5, May 2014.

13. Jeekel J. No abdominal drainage after Whipple's procedure. Br J Surg. 1992;79:182.

14. Lee CW, Pitt HA, Riall TS, Ronnekleiv-Kelly SS, Israel JS, Leverson GE. Low drain fluid amylase predicts absence of pancreatic fistula following pancreatectomy. J Gastrointest Surg, 2014.

15. Lu e cols. Systematic Review and Meta-Analysis of Pancreatic Amylase Value on Postoperative Day 1 After Pancreatic Resection to Predict Postoperative Pancreatic Fistula.

16. Petrowsky H, Demartines N, Rousson V, Clavien PA. Evidence-based value of prophylactic drainage in gastrointestinal surgery: a systematic review and meta-analyses. Ann Surg 2004;240: 1074-1085.

17. Sutcliffe RP, Battula N, Haque A, Ali A, Srinivasan P, Atkinson SW et all. Utility of drain fluid amylase measurement on the first postoperative day after pancreaticoduodenectomy. World J Surg (2012) 36:879-883.

18. VanBuren G2nd, Bloomston M, HughesSJ, etal.Arandomized prospective multicenter trial of pancreaticoduodenectomy with and without routine intra- peritoneal drainage. Ann Surg. 2014;259:605-612.

19. Witzigmann H, Diener MK, Kißenkotter S, Rossion I, Bruckner T, Werner B. No Need for Routine Drainage After Pancreatic Head Resection: The Dual-Center, Randomized, Controlled PANDRA Trial.

20. Yamaguchi M, Nakano H, Midorikawa T, Yoshizawa Y, Sanada Y, Kumada K. Prediction of pancreatic fistula by amylase levels of drainage fluid on the first day after pancreatectomy. Hepatogastroenterology. 2003 Jul-Aug;50(52):1155-8.

21. Yang J, Huang Q, Wang C.Postoperativedrainamylase predictspancreatic fistula in pancreatic surgery: A systematic review and meta-analysis. Postoperativedrainamylasepredictspancreaticfistulain pancreaticsurgery: A systematic review and meta-analysis. Int J Surg. 2015 Oct;22:38-45 